\title{
Impact of boarding secondary schools on students' achievement in mathematics in Bayelsa State, Nigeria.
}

\author{
John Aduwa, $P h D$ \\ Department of Science, Government Secondary School \\ Ogbia Town, Bayelsa State, Nigeria \\ Email: aduwajhn@gmail.com \\ Cell: +2348068353230
}

\begin{abstract}
The study examined the impact of boarding Secondary Schools on students' achievement in mathematics. The study was conducted in Ogbia Education Zone of Bayelsa State, Nigeria. Two research questions and their corresponding null hypotheses guided the study. A post-test only of quasi- experimental research design was adopted. Furthermore, a purposive sampling technique was used to select a sample size of 219 senior secondary school class 1 (SSS 1) mathematics students from a mixed model boarding secondary school. This school consisted of both boarding and day students. A Mathematics Achievement Test (MAT) was used to collect data from the students after a period of instruction that lasted for one full academic term. All data collected were analysed by the methods of mean, standard deviation and t-test statistics. The finding indicated that the establishment of the model boarding secondary schools by the Bayelsa State Government had a very significant impact on students' achievement in mathematics. The study recommended that more model boarding secondary schools should be established by the Bayelsa State Government.
\end{abstract}

Key words: Boarding students, Day students, Impact, Mathematics, Model, Secondary schools, Students' achievement.

\section{Introduction}

Mathematics is one of the core subjects in the secondary school level of education in Nigeria. It is a subject that required the critical reasoning of the learners to learn it better. For the development of the critical reasoning of the students, government at all levels, private individuals and mathematics researchers have developed different methods or ways that will enable the learners to learn the subject appropriately. In addition to the teaching methods or strategies adopted by mathematics teachers, government or private individual has resulted to another way of educating the students. One of such ways was the introduction of boarding school's system.

Boarding schools are schools where the owners of schools take the full custodian of both upbringing and academic well- beings of the learners under their care during the academic session. The owners of schools may be governments or private individuals. Although, boarding schools owned by private individuals are relatively very expensive compared to the boarding schools managed by the governments (Keystone, 2016).

On the definition of boarding school, British Council (2020) defined boarding school as a residential school where pupils live and study during the school year. Based on this definition, the students in the boarding schools were accommodated in the school compound by the management of such schools. This implies that the school management takes full care of the students under their control, both academic and feeding during the academic session. Also, Linden Boarding School Tours (2020) saw boarding school as a college preparatory institutions where students and teachers live and study together in a safe and secure school environment. Linden Boarding School Tours (2020) definition of boarding school indicated that staff of such schools should be equally accommodated alongside with the students in a more secure and conducive school environment. Boarding school is a school equipped with 
John Aduwa: Impact of boarding secondary schools on students' achievement in mathematics in Bayelsa State, Nigeria

rooms where the students live instead of living in their homes (Cambridge Dictionary, 1996). Also, Merriam-Webster (n.d) viewed boarding school as a school that provides meals and lodging for students. In addition, Hornby (2010) saw boarding school as a school where students can live within the school academic year.

On the meaning of day school, it is a school where the students come directly from their homes to school and left back home when school has closed for the day during the academic year. Ode (2019) quoted Ajayi (2002) and stated that, the day school system was embraced by parents because it enables them the opportunity of helping children in their school homework which eventually resulted in the improvement of the students' academic achievement.

A study conducted by Chaisemartin and Gurgand (2017) on the effects of boarding school for disadvantaged students in France. According to the authors, the result reveals that the disadvantaged students from boarding schools performed better than the day students in mathematics.

Boarding schools offered the students the opportunity to learn on their own without distraction from their parents, especially in the evening. Since the school management takes care of their both academic and feeding, the students were strictly monitored by the school. Even in some cases, extra classes were organized for students in the boarding schools during the academic session and even when the academic is not in session (holidays) by the owners.

There were some schools that operated both boarding and day schools. In a similar way, there were some schools that operated boarding schools only. With respect to school facilities, studies have shown that boarding schools possessed more facilities than the non-boarding schools (Maphoso \& Mahlo, 2017). The availability of these basic facilities attracted parents to enroll their children in the boarding schools despite the expensive nature of the schools. Furthermore, parents believed that the academic achievement of the students in the boarding schools will be better than those students in the nonboarding schools.

A study carried out by Sparks (2015) and discovered that boarding schools had potential ability of benefiting strong students in mathematics. According to Sparks (2015), strong students gained more knowledge in mathematics than the weak students. In some cases, weak students were left out because their parents were not residing in the school premises. In addition, boarding school is a disruptive form of schooling for students (Sparks, 2015).

Meanwhile, in the boarding schools, motivation, engagement, achievement, personality and psychological well-being of the students were put under control by the school management (Martin, Papworth, Ginns \& Liem, 2014). According to the authors, boarding schools had all it takes to improve both the academic and well-being of the learners when compared to the day schools.

Although, there were some problems associated with the boarding schools. One of such problems was bullying behaviour among the learners. This behaviour was common to both boarding and day students but was more among the students in the boarding schools (Pfeiffer \& Pinquart, 2014). According to the researchers, one of the reasons why this bullying behaviour was common mostly among the students in the boarding schools was as a result of selecting effects. Pfeiffer and Pinquert (2014) further stated that if this ugly behaviour was not properly checked, it may have had negative effect on the life of the learners during and after the secondary education.

Okoye and Nnamani (2018) did a study on the extent of academic 
John Aduwa: Impact of boarding secondary schools on students' achievement in mathematics in Bayelsa State, Nigeria

achievement of day and boarding secondary school's students in Anambra State, Nigeria. The two researchers employed a descriptive research design for their study. At the end of the data analyses, Okoye and Nnamani (2018) discovered that boarding students did academically better than the day students. One of the reasons given by Okoye and Nnamani (2018) for the finding was that, day students were distracted at home by their parents and others but boarding students were properly controlled by the management of the schools to face their studies seriously. Okoye and Nnamani (2018) concluded that lack of finance, educational facilities and inadequate infrastructures were the challenges that affected the academic achievement of both the day and boarding students in Anambra State. In addition, the two researchers recommended that students should be allowed to attend boarding schools and also the Anambra State Government should intervene by providing schools with academic and boarding facilities. On the contrary, Tayo (2003) discovered that with proper control of parents there was possibility that the day students may perform better than the boarding students. According to Tayo (2003), the achievement of the day students will depend largely on their parents if they were properly controlled. This is an extreme view because most of the parents at present do no longer pay more attention to their children education apart from paying their school fees and buying of school materials. But checking their children books after closing at home is not common. Day students prefer to play with mobile phones rather than reading their books at home. But in the boarding schools, students are not allowed to hold mobile phones by the boarding school's management. For instance, boarding students under the Bayelsa State Government educational scheme are not allowed to hold mobile phones of any type. Holding a mobile phone is against the constitution of boarding schools in the State.

A comparative study of student's performance in mathematics in boarding and day secondary schools in Pankshin Local Government Area of Plateau State (Fwinpak \& Dirgak, 2017). Fwinpak and Dirgak (2017) employed a comparative research design in their study. According to Fwinpak and Dirgat (2017), the finding indicated that there was a significant difference in the performance of students in boarding and day secondary school's external examination in mathematics. In addition, there was a significant difference between the performance of female boarding and day students in mathematics external examination. Fwinpak and Dirgak (2017) recommended that government should be fair in distributing educational materials to both the boarding and day secondary schools. Also, according to the researchers, qualified mathematics teachers should be recruited and posted to both boarding and day secondary schools fairly.

A study conducted by Ode (2019) on the effects of school type on secondary school students' academic achievement in social students. The school type according to Ode (2019) was day and boarding schools. Ode (2019) adopted a post-test only experimental design for the study. According to the author, the study made use of two groups-experimental and control groups. Ode (2019) further stated that experimental group consisted of day school students while the control groups had boarding school students. Social Studies Achievement Test (SOSAT) was the instrument used to collect data from ninety (90) social studies students from junior secondary schools. The students in the two groups were taught social studies for 9 weeks by only one social studies teacher (Ode, 2019). At the end of the $9^{\text {th }}$ week of the study, the post-test was administered to the students in the two 
John Aduwa: Impact of boarding secondary schools on students' achievement in mathematics in Bayelsa State, Nigeria

groups. On the data analyses, Ode (2019) stated that t-test was used. The finding of the study according to Ode (2019) showed that boarding school students did significantly better than the day school students in social studies. Finally, Ode (2019) recommended that day secondary schools owned by government and private individual should periodically organized workshops and seminars for their students in other to improve their achievement in social studies and other subjects.

On the achievement of male and female students in boarding and day schools, Scharff and Brady (2006) reported that female students in the boarding schools did better than the female students in the day schools. According to Scharff and Brady (2006), the reason was that female students in the day schools were over laboured with house-hold chores before going to schools which in most cases made them late to classes. In addition, this had affected the performance of day students. This finding of Scharff and Brady (2006) was conducted in Malawi. Also, Tayo (2003) agrees that male students did significantly better than the female students in mathematics.

Based on the enormous benefits derived from boarding schools with respect to the cognitive and effective domains of the learners, some State Governments in Nigeria had established schools with boarding facilities. One of such states was Bayelsa State.

Bayelsa State is a State with eight (8) Local Government Areas. Recently, Bayelsa State Government introduced fifteen (15) model secondary schools with boarding facilities. These model boarding schools with at least one school in each Local Government Area, were free to all qualified students. Some of these schools operated for both boarding and day students, while other schools were purely boarding. According to Dickson (2017), the former Executive Governor of Bayelsa Sate, the establishment of these model boarding secondary schools was as a result of discouraging students from taking to militancy. This was because, according to Dickson (2017), studies have shown that there was correlation between illiteracy and militancy in the South-South region of Nigeria. In these model boarding secondary schools, the students under the scheme were well taking care of by the Bayelsa State Government in terms of feeding and general well-beings of the learners. Since the creation of Bayelsa State, Nigeria in 1996, the State has no single public model boarding secondary school. When Hon. Seriake Dickson, the former Executive Governor of Bayelsa State came into power, he established these model boarding secondary schools. For the effective management of the model boarding secondary schools in the State, he established the Bayelsa State Education Development Trust Fund Board. This board was established by law. The board was charged with the responsibility of managing and controlling all the financial resources allocated to the smooth running of all the model boarding secondary schools. The boarding secondary schools' system is being financed by the Bayelsa State Government through the efforts of all the public and civil servants under the Government payroll. All the model boarding Secondary schools are well equipped with model facilities. Furthermore, the boarding students in each of the boarding schools are well fed, three (3) square meals a day in each of the academic term. The food given to the students in the boarding schools is very rich and contained all the classes of food.

Therefore, this study found out to what impact these model boarding secondary schools have on the academic achievement of mathematics students as compared to day students in Bayelsa State, Nigeria. 
John Aduwa: Impact of boarding secondary schools on students' achievement in mathematics in Bayelsa State, Nigeria

\section{Research questions}

1. Is there any difference between the mean achievement scores of boarding and day students in mathematics?

2. Is there any difference between the mean achievement scores of male and female boarding students in mathematics?

\section{Hypotheses}

The following hypotheses were tested at 0.05 level of significance:

1. There is no significant difference between the mean achievement scores of boarding and day students in mathematics.

2. There is no significant difference between the mean achievement scores of male and female boarding students in mathematics.

\section{Methods}

Design: The study employed a post-test only of quasi-experimental research design. The essence of this design is to avoid the school been distracted as a result of the study. All the students remained the way they are in the classrooms. The study made use of two groups- experimental and control groups. Experimental group consisted of boarding mathematics students in the model secondary school. Meanwhile, control group contained day mathematics students in the same model secondary school.

Sample: A purposive sampling technique was used to select two hundred and nineteen (219) Senior Secondary School class 1 (SSS1) mathematics students from a public owned mixed model secondary school that operated both boarding and day students in Ogbia Education zone. From the two hundred and nineteen (219) mathematics students, one hundred and twenty - four (124) were boarding students while ninety-five (95) of them were day students. These sampled model Senior Secondary School class 1 (SSS1) mathematics students (boarding and day students) received mathematics instruction together in the same classes. In this particular public owned model secondary school, it has three arms of classes and all the arms were used for the study. The essence of this one public owned model secondary school selected for the study was to ensure that both boarding and day students were exposed to the same mathematics scheme of work by the teacher.

Instrument development/validation: The instrument for the study was a Mathematics Achievement Test (MAT) constructed by the researcher. It consisted of 20 objective questions drawn from Senior Secondary School class 1 (SSS1) mathematics curriculum in the 2018/2019 third term academic session. On the validation of the Mathematics Achievement Test (MAT), content and construct validity in conjunction with the experts in the field of mathematics and education were used. For the content validity, a table of specification was used to ensure that all the items in the Mathematics Achievement Test (MAT) are spread in the analysis, synthesis and evaluation of the Bloom taxonomy of objective in the table of specification. To ensure that all the items in the Mathematics Achievement Test (MAT) are not too difficult or too simple, item analysis was carried out on the instrument (construct validity). Firstly, the researcher drafted 35 items of the Mathematics Achievement Test (MAT). Under the item analysis, two (2) indices called item difficulty level index and the discrimination index, were computed. Before the item analysis, the 35 items Mathematics Achievement Test (MAT) was administered to a pilot secondary school different from the sampled school.

Tropical Journal of Education, Volume 2, Numbers 1/2, 2020 
John Aduwa: Impact of boarding secondary schools on students' achievement in mathematics in Bayelsa State, Nigeria

At the end of the test during the pilot stage, the Senior Secondary School class 1 (SSS1), 15 of them were scored accordingly. The scores from the pilot stage were used to compute the two indices. The item difficulty level index was determined by the percentage of students that got the right answer out of the total students in the pilot group. For the discrimination index of the item, the scripts of the fifteen (15) students were arranged in order of magnitudes of the scores, the highest scores being on top and the lowest scores below. Then, six (6) scripts were counted from the top and these formed the upper 6 students. Also, six (6) scripts were counted from the bottom which represented the lower six (6) scripts. The remaining three (3) scripts represented students in between were not used. At the end of the item analysis, fifteen (15) items were rejected left twenty (20) items and was used for the study. For the determination of the consistency of the Mathematics Achievement Test (MAT), it was administered to twenty-five (25) Senior Secondary School class 1 (SSS1) in another different public secondary school in Bayelsa State, Nigeria. A 0.73 reliability coefficient of the instrument was obtained using Kuder - Richardson formula 21. This number is more than 0.5 which means that, the instrument is reliable.

Treatment procedure: The boarding and day mathematics students in the model sampled secondary school owned by the Bayelsa State Government were taught by one qualified mathematics teacher. The teacher made use of third term mathematics scheme of work drawn from the current mathematics curriculum for Senior Secondary School class 1 (SSS1). During the mathematics instruction, both boarding and day mathematics students were mixed together in the same classes of three (3) arms. In other words, the students received instruction together. The experiment of the study actually lasted for eight (8) weeks in the 2018/2019 third term academic session. During the administration of the Mathematics Achievement Test for the students towards the end of the experiment, the boarding and day mathematics students were separated into experimental and control groups, respectively. This implies that the boarding students were in another two classes for the test, and the day students were in another two classes for the same test. The essence of this is to avoid cheating among the students. During the conduct of the post-test for the students, the researcher actually solicited the helps of some of his colleagues for the supervision of the test. At the end of the test, all the scripts were retrieved from the students, and hence, ends the experiment.

Data analysis: The scoring of students' responses on the Mathematics Achievement Test (MAT) was on a minimum of zero (0) and maximum of 20 marks. Mean, standard deviation and t-test were used to analysed the data collected.

\section{Results}

Research question 1: Is there any difference between the mean achievement scores of boarding and day students in mathematics? The research question was answered with the data in Table 1.

Table 1: Mean and standard deviation of boarding and day students in mathematics

\begin{tabular}{lccc}
\hline \multicolumn{1}{c}{ Groups } & $\mathbf{N}$ & Mean $(\overline{\mathbf{x}})$ & SD \\
\hline Experimental & 124 & 11.52 & 3.40 \\
Control & 95 & 7.77 & 2.87 \\
\hline
\end{tabular}

From the Table shown above, the mean scores of experimental group (boarding students) and control group (day students) were 11.52 and 7.77,

Tropical Journal of Education, Volume 2, Numbers 1/2, 2020 
John Aduwa: Impact of boarding secondary schools on students' achievement in mathematics in Bayelsa State, Nigeria

respectively. A score of 3.75 was the difference between the mean achievement scores of boarding and day students. The standard deviation of experimental group (boarding students) was 3.40 and that of the control group (day students) was 2.87 .
Research question 2: Is there any difference between the mean achievement scores of male and female boarding students in mathematics? Data in Table 2 were used to answer this question.

Table 2: Mean and standard deviation of male and female boarding students

\begin{tabular}{llcl}
\hline \multicolumn{1}{c}{ Variables } & N & Mean $(\overline{\mathbf{x}})$ & S.D \\
\hline Male & 68 & 12.19 & 3.63 \\
Female & 56 & 10.70 & 2.92 \\
\hline
\end{tabular}

The mean scores of male and female boarding students in mathematics were 12.19 and 10.70 , respectively as indicated in Table 2. The mean difference between the scores of male and female students was 1.49 . The standard deviations of male and female boarding students were 3.63 and 2.92 , respectively.
Hypothesis $\left(\mathrm{Ho}_{1}\right)$ : There is no significant difference between the mean achievement scores of boarding and day students in mathematics. This hypothesis was tested with the data in Table 3.

Table 3: t-test summary table showing the achievement of boarding and day students

\begin{tabular}{lccccccc}
\hline \multicolumn{1}{c}{ Groups } & $\mathbf{N}$ & $(\overline{\mathbf{x}})$ & SD & Df & t-cal & t-critical & Decision \\
\hline Experimental & 124 & 11.52 & 3.40 & \multirow{2}{*}{217} & \multirow{2}{*}{8.64} & \multirow{2}{*}{1.96} & $\mathrm{Ho}_{1}$ not accepted \\
Control & 95 & 7.77 & 2.87 & & & & \\
\hline
\end{tabular}

From Table 3, the $t$-calculated value of 8.64 was greater than the t-critical value of 1.96. Based on this development, $\mathrm{Ho}_{1}$ was not accepted. This implies that boarding students did significantly better than the day students in mathematics.
Hypothesis $\left(\mathbf{H o}_{2}\right)$ : There is no significant difference between the mean achievement scores of male and female boarding students in mathematics. Data in Table 4 were used to test this hypothesis.

Table 4: t-test summary table showing the achievement of male and female boarding students in mathematics

\begin{tabular}{lccccccc}
\hline Variables & $\mathbf{N}$ & $(\overline{\mathbf{x}})$ & SD & Df & T-cal & t-critical & Decision \\
\hline Male & 68 & 12.19 & 3.63 & \multirow{2}{*}{122} & 0.72 & 1.96 & $\mathrm{Ho}_{2}$ accepted \\
Female & 56 & 10.70 & 2.92 & & & & \\
\hline
\end{tabular}

The t-calculated value of 0.72 was less than the t-critical value of 1.96 as reported in Table 4. Based on this result, null hypothesis $\left(\mathrm{Ho}_{2}\right)$ was accepted. This implies that the difference between the mean achievement scores of male and female boarding students in mathematics which stood at 1.49 was not significant.

\section{Discussion}

In discussing the first result of this study, the paper discovered that boarding students with the mean score of 11.52 achieved significantly better than the day students with the mean score of 7.77 in mathematics. The implication of this result

Tropical Journal of Education, Volume 2, Numbers 1/2, 2020 
John Aduwa: Impact of boarding secondary schools on students' achievement in mathematics in Bayelsa State, Nigeria

was that the establishment of these model boarding secondary schools by the Bayelsa State Government had positive impact on boarding students' academic achievement in mathematics. The excellent achievement of Senior Secondary School class 1 (SSS1) boarding students in mathematics may be traced to measures such as evening prep, standard boarding facilities and admission procedures put in place by the Bayelsa State Government. The researcher of this study has strong confidence on the outcome of the study. The study was conducted where nearly all the variables, apart from the variable under consideration (boarding), that might affect the academic achievement of boarding and day students in mathematics where to some extend controlled by the researcher. Variables such as teacher' factors, subject' factors, school location factor and among others remained the same in both the experimental and control groups. Also, the sampled boarding and day students during the study were not aware that they were been investigated. This is because the students were in their normal arrangement in the three classes of Senior Secondary School class 1 (SSS 1) during the experiment, except on the last day of the experiment where the boarding and day mathematics students were separated into the experimental and control groups during the post-test, respectively. In all, this finding was corroborated with the findings of these previous researchers such as Chaisemartin and Gurgard (2017), Sparks (2015), Martin, et al (2014), Ode (2019), Okoye and Nnamani (2018), and Fwinpak and Dirgak (2017). These researchers discovered that boarding schools had potential ability of improving boarding students' academic achievement in mathematics based on humans and materials facilities provided by the owners of such boarding schools.

The study also discovered that both male and female boarding students did very well in mathematics. Although, male boarding students with the mean score of 12.19 tends to achieved better than the female boarding students in mathematics, but the difference in their mean scores was not significant. This result was supported by the findings of Mkandawire (2013) and Tayo (2003).

\section{Conclusion}

The study concluded that the establishment of the model boarding secondary schools by the Bayelsa State Government had improved the achievement of Senior Secondary School class 1 (SSS 1) boarding students in mathematics. Both male and female boarding students performed better in mathematics but in favour of the male students.

Based on the research findings and conclusion which emanated from the outcome of the study, the researcher made the following recommendations:

1. More model boarding secondary schools should be established by the Bayelsa State Government.

2. The summer holiday lesson presently organized during the third term long holiday for boarding students should be for all classes in the Senior Secondary School level instead of one class (SSS2) that was currently practiced by the Bayelsa State Government.

3. Evening classes should be organized for both boarding and day students in mathematics at the Senior Secondary School level for at least two times in a week. This will further enhance their achievement in the subject.

4. Both male and female mathematics students should be encouraged to learn mathematics by their mathematics Teachers.

5. Workshops and seminars should be organized for mathematics teachers periodically by the Bayelsa State Government through the Ministry 
John Aduwa: Impact of boarding secondary schools on students' achievement in mathematics in Bayelsa State, Nigeria

of Education and Post Primary Schools Board.

6. More classrooms (School buildings) in the already exist boarding schools should be put in place by the Bayelsa State Government for the accommodation of more boarding and day students.

7. Also, more qualified mathematics teachers should be recruited and posted to model boarding secondary schools by the Bayelsa State Government.

8. More educational mathematics instructional materials such as Charts, board rulers, board pair of compasses, graph boards and other necessary materials should be provided by the State Government. On the provision of mathematics textbooks to all the model boarding schools, Bayelsa State Government should be commended.

9. Mathematics laboratory should be provided to all the model boarding secondary schools by the Bayelsa State Government. The essence of this is that, if eventually the State Government provided the recommended mathematics instructional materials, all will be kept in the laboratory for future use.

\section{Acknowledgements}

I acknowledge the mathematics teacher, my colleagues and students of the sampled model boarding secondary school for their efforts toward the completion of the study. I also thank all the authors whose works were consulted during the course of the study.

Finally, with respect and honour, I equally thank my former lecturer, Prof. Chukunoye Enunuwe Ochonogor, for his excellent roles demonstrated in my academic life over the years. Furthermore, may God Almighty continue to bless you and your family in Jesus name, amen.

\section{References}

Ajayi, F. A. O. (2002). School environment and learning. Lagos, Genuine printers.

British Council (2020). Boarding School. Retrieved from https://studyuk.bristishcouncil.org

Cambridge Dictionary (1996). Cambridge academic content dictionary.

Cambridge University press

.Retrieved from https://dictionary .cambridge.org

Chaisemartin, B.L.C and Gurgand, M. (2017). Effects of a boarding school for disadvantaged students. American Economic Journal Applied Economics, 9(1), 140-164, doi: 10.1257/app.20150090

Dickson, H.S. (2017). Why I introduced boarding school system in Bayelsa state. Leadership Nigerian Newspaper.

Fwinpak, S. E. and Dirgak, S. L. (2017). A comparative study of students, performance in mathematics in boarding and day secondary schools in Pankshin Local Government Area of Plateau State. Unpublished N.C.E Project work, Department of Mathematics, Federal College of Education, Pankshin, Nigeria.

Hornby A. S. (2010). Oxford advanced learner's dictionary ( $8^{\text {th }}$ edition). Oxford, Oxford University press.

Keystone, T. (2016). Top five reasons to choose day school over boarding school. Retrieved from https://key stonetutors.com

Linden Boarding School Tours (2020). Boarding school. Retrieved fromhttps://www.boardingschoolto urs.com

Maphoso, L.S.T and Mahlo, D. (2017). Basic facilities and academic achievement: A comparative study 
John Aduwa: Impact of boarding secondary schools on students' achievement in mathematics in Bayelsa State, Nigeria

between boarding and nonboarding schools. International Journal of Educational Sciences, 6(2),309-315, doi:10.1080/09751122.2014.11890 142

Martin, A.J, Papworth, B, Ginns, P and Liem, G.A.D. (2014). Boarding school academic motivation and engagement, and psychological well-being. A large-scale investigat ion. American Educational Rese arch Journal, 51 (5), 10071049,doi:10.3102/000283121453 2164

Merriam-Webster (n.d). Boarding school. In Merriam -Webster.com diction ary._Retrieved from https://Merr iam-webster.com/dictionary /boarding \%20 school.

Mkandawire, C.(2013). Teachers' questio ning techniques in mathematics, at grade 11 level: The case of four selected secondary schools in Petanke district. An unpublished M.Ed Dissertation, University of Zambia, Lusaka.

Ode, D. (2019). Effects of school type (day school and boarding school) on secondary school students' academic achievement in social studies. International journal of
Education (IJE), 7(1),1-22, doi: 10.5121/ije.2019.7102

Okoye, F. O. and Nnamani, P.C (2018). Extend of academic achievement of day and boarding secondary school students in Anambra State, Nigeria. International Journal of Scientific Research and Management, 6(1), 21-26, doi:10.18535/Ijsrm/v6I1.El 03

Pfeiffer, J.P and Pinquart, M. (2014). Bullying in German boarding schools. A pilot study. School Psychology International, 35(6), 580-591, doi:10.1177/0143034314 525513

Scharff, X. and Brady, A. (2006). Baseline study. attitudes on girl's education in Malawi. The Advancement of Girls Education Scholarship Fund. Washington D.C, World Bank.

Sparks, S. (2015). Study: Boarding schools don't benefit all students. Education week. Retrieved from www.edwee k.org > 2015/02/18>st...

Tayo, O. (2003). The impact of deboarding on secondary school student's performance in economics in Irepodun Local Government Area of Kwara State. Unpublished B. Sc(Ed) Project Submitted to Arts and Social Science Education Department, University of Ilorin, Kwara State. 